\title{
Information Presentation of Professional Structure of Russian Society in Mass Media
}

\author{
Tatiana Borisovna Malinina ${ }^{1}$, Irina Borisovna Dadianova ${ }^{2}$, Elena Eugenievna Tarando ${ }^{3}$, Nikolay Alexandrovich \\ Pruel $^{4} \&$ Valeriy Aleksandrovich Malychev ${ }^{4}$ \\ ${ }^{1}$ Faculty of Sociology, Department of Social Analyses and mathematical methods in Sociology, Saint-Petersburg \\ State University, Saint-Petersburg, Russian Federation \\ ${ }^{2}$ Faculty of Information Technologies, Department of Information Systems and Multimedia Saint-Petersburg \\ State Institution of Culture, Saint-Petersburg, Russian Federation \\ ${ }^{3}$ Faculty of Sociology, Department of Economic Sociology, Saint-Petersburg State University, Saint-Petersburg, \\ Russian Federation \\ ${ }^{4}$ Faculty of Sociology, Department of social management and planning, Saint-Petersburg State University, \\ Saint-Petersburg, Russian Federation \\ Correspondence: Tatiana Borisovna Malinina, Building 3, fl. 45, Olga Forsh str., Saint Petersburg, 195269, \\ Russian Federation. Tel: 8-921-937-5891.
}

Received: March 11, 2015 Accepted: March 30, 2015 Online Published: May 22, 2015

doi:10.5539/res.v7n9p41 URL: http://dx.doi.org/10.5539/res.v7n9p41

\begin{abstract}
The paper analyzes the processes of mass media data content impact on social processes taking place within society. The key role of modern mass media in person's life as a society's information base is brought into focus. In this context the problem of circulating information quality and adequacy of information presentation of social processes of mass media is stated. The results of mass media activity influence many social processes, particularly the process of society's professional structure formation. When commenting profession representatives and professional activity it forms certain image of society's professional structure.

Mass media influence on real occupational skill structure of society makes itself felt through the formation of social \& professional hierarchy in person's consciousness, the hierarchy closely related to the idea of status value of one or another profession, influencing on occupational choice.

The results of the empiric study of information presentation of professional structure of the Russian society in mass media realized by means of content analysis of print media publications are represented. Regression model is built based on collected data to study interrelation between a number of factors such as actual professional structure of the Russian society, information presentation of professional structure created by mass media, need for specialists, average salary, status value of professions, and various professional groups.
\end{abstract}

Keywords: mass media, society's professional structure formation, social processes modeling

\section{Introduction}

The modern stage of human civilization development is characterized by the gradual transition to the new type of social structure - so called information society. The consequences of this process are revealed in accelerating informatization of all areas of activity, formation of unified information space, and also in an increase in availability of various types of information and target audience accumulation.

For today mass media plays a critical part as a society's institute, which provides social communication, making a connection between different parts of socium. Mass media has not only become a mediator between an individual and the world, but is - to some extent-information base of society, that is why a question of the quality of circulating information and adequacy of information presentation of social processes arises.

In the context of modern information society seized by the processes of globalization and world economic crisis, information potential of mass media is regularly used for purposes of manipulation by the social conscience and servicing mass consumer culture. Manipulation by information leads to sudden drop of transmitted information and loss of reality presentation objectivity. This tendency clearly appears during various crises-economic, 
political, and social.

Owing to popularity, availability, and ability to meet various audiences' information needs, mass media increasingly extends the sphere of its influence. Mass media influences the formation of value system, which defines person's activity, his life goals, behaviorial models.

It should be noted that mass media activity results exercise influence upon many social processes, including the process of society's professional structure formation. Professional activity is one of the most important characteristics of person's social status, his place in social hierarchy. Therefore issues regarding professional activity of people have been socially important, attractive for studies of various kinds. Since mass media is the most influential information source in the modern society, one may suppose that a person gets the best part of information on society's professional structure from there. Based on personal habits, stereotypes and newly obtained information people form opinion of society's social \& professional hierarchy, the important characteristics of which is professions' status value.

Popularization of particular professions in mass media is one of the causes of such phenomena as all-time high competition to some faculties, periodic labor-market glut with specialists in certain areas of activity, on the one part, and shortage of specialists of low-popular professions on the other part, that ultimately leads to imbalance of society's professional structure.

It is estimated that image of society's professional structure in mass media forms priorities in the process of person's occupational choice that ultimately impacts actual professional structure.

\section{Literature Review}

Philosophers, sociologists, cultural specialists, psychologists in their works express general consensus that the significance of information component in the modern society significantly increases (Castells, 2000; Afanasev, 1975; Wiener, 1958; Shannon, 1963, etc.). Specifically information transmitted by mass media largely defines life style of modern people, values they begin to follow when choosing model of daily behaviour (Bagirov, 1978; Belyaev, 2005; Boretsky, 1993; Egorov, 1998; Malinina, 2014; Mihalkovich, 1996, etc.). Many researchers (in particular, Baudrillard, 2000, 2006; Toffler, 2010), stress unreadiness of modern human to perception of vast amount of information and emphasize the fact of its transmission's fragmentation.

In the works of Baudrillard's In the Shadow of the Silent Majorities or the End of the Social and Consumer Society, Ershov's Human needs, Zdravomyslov's Needs. Interests. Values the significance of such factors as consumption and hedonism in the formation of post-industrial society's mass consciousness content is made an emphasis on (Baudrillard, 2000, 2006; Ershov, 1990; Zdravomyslov, 1986).

In $20^{\text {th }}$ century the effectivity problem of mass media activity, its impact on audience and society development drew academics' attention. Over the history of issue-related researches the development of two essential approaches to the study of the process of mass media influence on audience are clearly seen. According to the first approach academics and researchers state that mass media exercises major influence on audience. In the contest of the second approach the importance of mass media in this process is minimized, its impact is defined by a number of mediate factors (Bryant \& Oliver, 2009; Lule, 2014).

The first stage of studies, marked by empowering of mass communications with almost limitless influence on public opinion and people behaviour, was represented by west academics' works (Lasswell, 1927; Schramm, 1960; Lippmann W, 2004).

At the second stage $-40-60 \mathrm{~s}$ of $20^{\text {th }}$ century — due to a number of empiric studies faith in press' omnipotence gave way to more reserved treatment of its capability of influence on mass audience (Berelson, 1966; Hovland, Janis, \& Kelly, 1964; Lazarsfeld, 1940; DeFleur \& Ball-Rokeach, 1996).

The next stage, conditionally dated by the beginning of $70 \mathrm{~s}$ of $20^{\text {th }}$ and has lasted to date, is defined as return to scientific paradigms of the first stage changed by new social realities. Key representatives of this period are H. M. Mc Luhan, G. Gerbner, D. Mc Quail.

Prevalence of management tools of information, in other words-human consciousness manipulation means or public opinion formation means are analyzed in G. Lasswell's Propaganda, Communication, and Social Order, (Lasswell, 1927), W. Lippmann's Public Opinion (Lippmann, 2004), J. Zaller's The Nature and Origin of Mass Opinion (Zaller, 2004). The authors consider mass consciousness manipulation a systematic management by way of information coming to dissemination of specific messages and limitation of others, i.e. using censor for the purpose of persuasion of recipient to act in accordance with various financial and political groups' interests.

In turn, in A. Giddens' How Globalization is Reshaping Our Lives, J. Habermas' Moral Consciousness and 
Communicative Action, G. Schiller's Consciousness Manipulators a wide use of manipulative technologies for purposes of society management is criticized as it leads to the aggravation of social disparity and destruction of public sphere of information (Giddens, 2004; Habermas, 2000; Schiller, 1980).

A great deal of research studies are concerned with issues of social stratification in general and professional stratification in particular, among which the works of Russian and American sociologists Sorokin P. A. are considered to be fundamental. He states that existence of professional stratification becomes established based on two main groups of facts. Firstly, it's obvious that specific classes of professions have always been upper social strata, while other professional groups have almost always been at the base of social cone. Secondly, professional stratification phenomenon is also found within each professional sphere (Sorokin, 1970).

Sorokin also comes to the point that professional stratification in general view can be demonstrated in the form of profession pyramid, on the top of which there are professions exercising a function of control and organization, and at the foot-blue-collar jobs, less privileged and less paid. Since professional stratification is characterized by specific altitude, number of floors, and profile, the pyramid's look varies depending on each society.

Outstanding German sociologist Max Weber also gave much prominence to stratification issues in his academic endeavors. The basis of Weber's theory consists of three factors or measurements. The first factor is economic status or wealth as a complex of all material valuables a person owns, including his income, land, and other property items. The second is power as ability to bend other people to your will, use your own discretion. The third is status value (as a social status basis) in the form of recognition and respect of subject's merits, appreciation of his acts (Weber, 1991). As well as Sorokin, Weber point out three types of stratification in society: economic, political, and professional.

Generalizing definitions of different researches we understand society's professional structure as an entire set of professions in society grouping by various criteria: area of activity, income level, level of necessary education and others, and their interrelation based on hierarchic order, and also social positions, which define person's belonging to one or another professional group.

Russian society's professional structure studies have been and remain socially important. They received much attention in the Soviet times. The trend concerned with professions' status value and its impact on professional structure's formation was especially popular. Such academics as Filippov F. R., Cherednichenko G. A., Shubkin V. N. et al (Filippov, 1980, 1989; Cherednichenko \& Shubkin, 1985) made a contribution in this trend's development.

In 1994 Russian Classifier of Occupations was put into effect in Russia, year later-Russian National Classifier of Occupations of Employees, Positions of Civil Servants and Wage Category. These Classifiers are a constituent part of the Russian Federation's Unified system for classifying and coding information.

Russian Classifier of Occupations (OKZ) is a systematized list of labor activities, which are carried out in the territory of the Russian Federation. It allows achieving the uniformity of their names and providing opportunity to carry out statistical comparisons, accounting and analyzing. OKZ classification unit is a kind of labour activity (occupation), the base of which is classification (profession skill) and field of expertise. Objects of classification are homogeneous (in the context of work content) enlarged groups of professions of workers and positions of employees.

\section{Methodology and Methods}

The results of mass media impact on the formation of professional structure of Russian society are presented in this paper. Study purpose involved analysis of how far the image of professional structure created by mass media is adequate to the factual professional structure of Russian society. In this respect more specific tasks were defined. The first task is to carry out content analysis study of newspaper texts in order to collect information; the second task is to match factual professional structure and its image in mass media to confirm or reject the image distortion hypothesis.

The object of research is information image of professional structure of Russian society in mass media, which is a set of statements about various professions' representatives and directly about professions of frequent occurrence in mass media materials. Society's professional structure presentation in mass media includes two components: reflexive (informative aspect of messages) and estimative (communicator's treatment of profession). The subject of research is mass media mechanisms of influence on society's professional structure formation.

Society's professional structure is understood to be a set of professions in society grouping by various criteria: area of activity, income level, level of necessary education and others, and their interrelation based on hierarchic 
order, and also social positions, which define person's belonging to one or another professional group.

Mass media forms specific image of society's professional structure commenting professions' representatives and professions themselves. Given this, professions' representatives are provided with specific qualities, characteristics or features. Since people's views concerning any issue are subject to the influence of personal established stereotypes and newly obtained information, one may suppose that based on the society's professional structure image transmitted by mass media, individuals build their own social and professional hierarchy, based on which decision on occupational choice is made. In such a way mass media influence is mediated in the change of society's real professional \& qualification structure.

Thus, mass media focusing on the coverage of the limited net of professions, whereby indirectly reflects social values and needs concerning the latter. The result of such actions is a distorted image of society's professional structure, which is perceived by individuals, influencing the system of the audience's qualification \& professional preferences.

The empiric base of the study consists of

- The materials of statistical books of Federal State Statistics Service of the Russian Federation, Federal State Service of Employment of Population of the Russian Federation;

- Legal documents: All-Russia Classifier of Occupations, All-Russia National Classifier of Occupations of Employees, Positions of Civil Servants and Wage Category;

- Data base of National Committee of Statistics of Russia, Department of Labor (www.gks.ru, www.labor.ru);

- Russia Public Opinion Research Center data base (http://wciom.ru/);

- The results of our own empiric study carried out by means of the following methods: publications content analysis, correlation \& regression analysis.

\section{Results and Discussion}

In the course of empiric data collection the analysis of materials of popular weekly newspaper Argumenty i Fakty was carried out using the method of content analysis (260 texts analyzed, randomly selected from the issues of 2013). References to professions were recorded in 182 texts (70\% of total). In the course of the study 745 references were recorded, which related to 82 different professions. In Russian National Classification of Occupations of Employees, Positions of Civil Servants and Wage Category mention is made of about 8 thousand of professions and positions existing within the territory of the Russian Federation. Correspondingly, in text analyzed there's a small share of professions - approximately $1 \%$ of existing ones.

These statement is a prove of an important hypothesis that the best part of professions remains beyond the scope of mass media attention. Therefore it is possible make a conclusion that reader obtains information only on limited amount of professions, which for one reason or another attract mass media interest at the given moment.

Leaders by the number of references are the following professions shown in Table 1.

Table 1. Leading professions by reference frequency

\begin{tabular}{lll}
\hline Profession & References number & In \% \\
\hline official & 141 & 18.9 \\
journalist & 64 & 8.6 \\
doctor & 55 & 7.4 \\
senior manager & 43 & 5.7 \\
musician & 37 & 4.9 \\
\hline
\end{tabular}

Total references: 745

Further-scientist, law enforcement officer, lawyer, actor. Each profession was mentioned about 30 times that comprises $4 \%$ of total number of references. Teacher references' frequency is approximately $3 \%$. Thus, the amount of frequencies of the first ten professions is 506 references (about $68 \%$ ).

Thus, references frequency distribution shows the existence of profession hierarchy in press materials. This is reflected in the fact that some professions are mentioned many times more frequently than others. Other fact 
suggests heighten interest in the professional activity of certain kind.

References grouping (Figure 1) was also carried out in accordance with occupations categories of All-Russia Classifier of Occupations (Table 2).

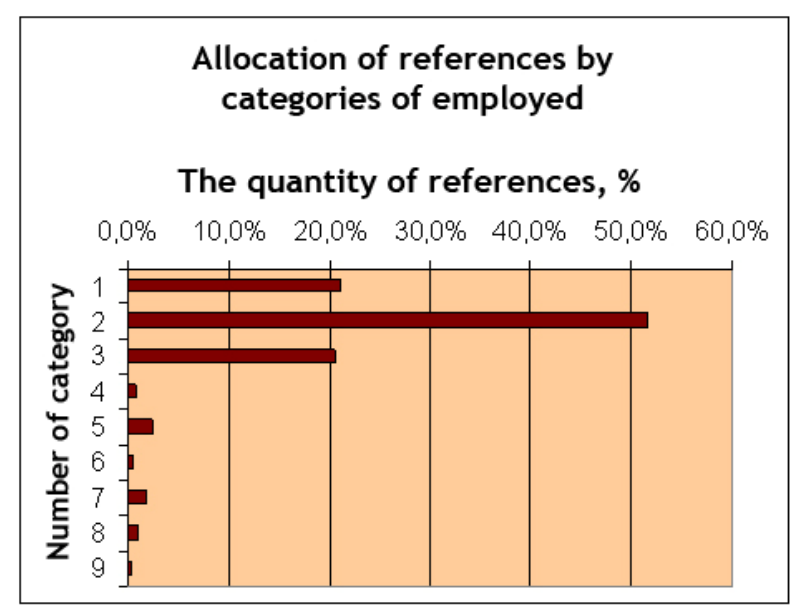

Figure 1. Distribution of professions references by employed population categories

Table 2. Correspondence of category number to its name

\begin{tabular}{|c|c|}
\hline No. & Categories of the employed (OKZ) \\
\hline 1 & Heads of organizations and enterprises and structural sub-divisions (services). \\
\hline 2 & Specialists of higher level of qualification. \\
\hline 3 & Specialists of medium level of qualification. \\
\hline 4 & $\begin{array}{l}\text { Workers engaged into preparation of information, drawing up of documentation, accounting and } \\
\text { servicing. }\end{array}$ \\
\hline 5 & Workers of services sector, housing and utilities infrastructure, trade and related types of activity. \\
\hline 6 & Qualified workers of agricultural, forest, hunting sectors, pisciculture and fishery \\
\hline 7 & $\begin{array}{l}\text { Qualified workers of industrial enterprises, artistic business, construction, transport, communication, } \\
\text { geology and exploration. }\end{array}$ \\
\hline 8 & Operators, machine politicians, machinists of units and mechanisms. \\
\hline 9 & Unskilled labour. \\
\hline
\end{tabular}

In analyzed publications the level of interest in professional activity issues is sufficiently high. However journalists take interest in and, consequently, deal with limited number of professions. It was also observed that in the majority of cases ( $85.6 \%$ of references), information on profession comes from a journalist, and not from a specialist in the given area of concern.

Referenced professions were also classified by areas of activities (Figure 2). 


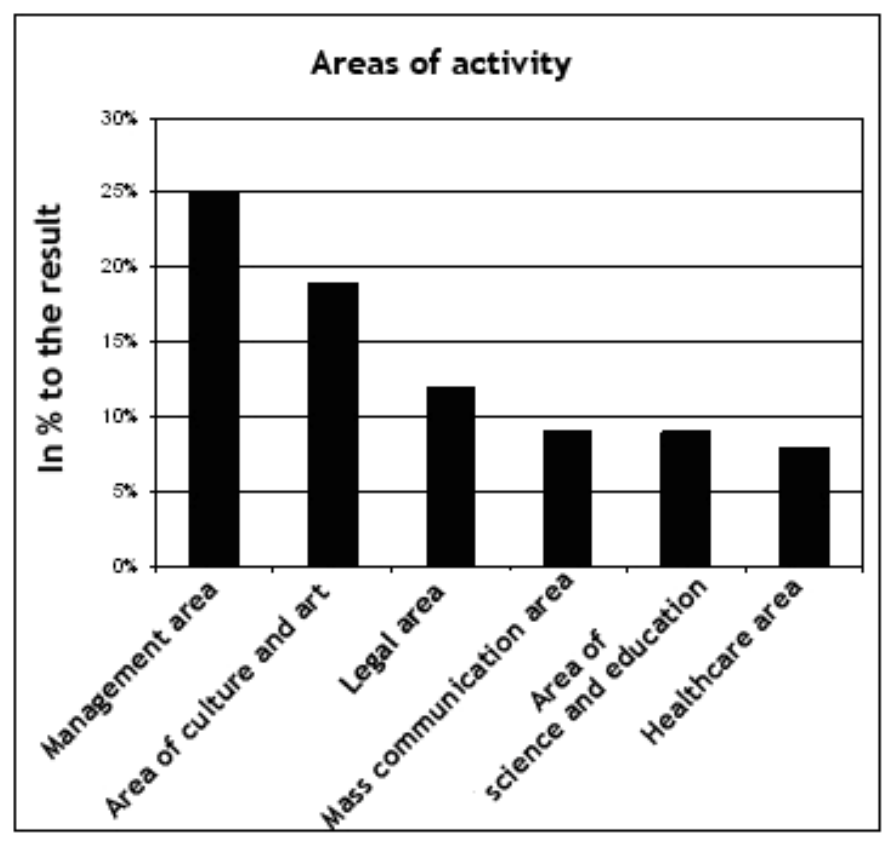

Figure 2. Professions distribution graph by areas of activities

Management area is a leading one. $25 \%$ of all references were made to it. 4 professions relate to management area: official, senior manager, manager and administrator. (The sum of references is 190)

Then the area of culture and art goes. This area is represented most variously and includes 15 professions (actor, musician, writer, director, painter, etc.). The sum of references frequencies is 139 , or $19 \%$ of total studied.

Legal sphere ranks third. It includes professions of lawyer, law enforcement officer, and forensic examiner. Legal sphere makes $12 \%$ of all references.

Mass communication area (professions: journalists, public relations consultant) and the area of science and education (scientist, educational institution director, teacher, kindergarten teacher) rank fourth - by $9 \%$ for each area.

Then healthcare area goes (doctor, nurse) $-8 \%$.

It's interesting that majority of referenced professions requires higher education. The amount of references to professions, which don't require higher education, was 55 , or about $7 \%$.

Thus, profession distribution by activity areas also confirms the presence of interest on the part of newsmen to certain types of activity.

It will be recalled that communicator is a source (author) of message. In our case this role is to be given to an author of statement about profession recorded in written text (newspaper). Consequently, both the article's author - journalist — can be a communicator, and any other subject commenting on the given topic and cited by a journalist.

If reference to specific profession was found in dictionaries, which belong to its representative, its reference was coded as "personal". If profession was mentioned by journalist or other person, who doesn't belong to this profession, the reference was coded as "impersonal".

References of impersonal nature made a major part among all references. In total 623 of such-like references were found, that made approximately $85.6 \%$ of total number of references. There were $121(16.4 \%)$ personal references correspondingly.

Thus, we can conclude that the following statement is accurate for analyzed texts. The reader gets the best part of information on professions not from profession representatives, but "casual observers", i.e. journalists, who do not always have sufficient competence and storage of knowledge for accurate coverage of activity of some specialists. Thus, the reader forms his idea of one or another profession based on journalist's point of view.

In the course of text processing the communicator's attitude to profession (or to profession representative) was 
registered about which he commented. The category of attitude included three units of analysis: positive, negative and neutral attitude (“+”, “-”, “ 0 ”). Two first types of attitude forms the group of emotionally coloured attitudes.

All set was divided into two groups: expressive and neutral statements. The first group makes $21.5 \%$ (161 ref.), and the second- $78.5 \%$ (587 ref.) of total amount of references. Thus, the better part of statements about professions has no emotional message.

In the group of expressive references negative attitude was recorded 93 times (12.4\% of general), and positive $-68(9.1 \%)$. In total- 161 or $21.5 \%$.

In the group of references of personalized nature (people speak about their profession) the part of emotionally coloured references (in relation to the total number of references in personal group-123 references) increases 1.6 times and makes $34 \%$ (in comparison with $21.5 \%$ in total). Here we should underline that in the group there are $23 \%$ of negative statements and $11 \%$ of positive statements. However, in the group of impersonal statements there is 1.2 times decrease of part of emotional references (18\% from total by groups). $8.8 \%$ of references are of positive character and $10.2 \%$ - of negative. Consequently, we can suppose the holders of professions are being more interested in their statements, than "outside observers". Taking into account these matters, we should add that in the statements of specialists the part of negative statements is bigger. The correlations between negative and positive statements for personal and impersonal groups makes up 2.1 and 1.2 correspondingly. On the assumption of all the above-said we can conclude that the representatives of professions manifest negative emotions and criticize their profession and coworkers more often than journalists.

One of analysis categories was declared as "The subject's gender" (the quantitative characteristics of reference subject). In the frameworks of the present category there were three units of analysis fixed: all the representatives of mentioned profession (when suggesting the profession in whole), the group of people and one man - the holder of profession.

As a result of analysis of the category it was found that in the majority of statements the subject is being one man. To say more specifically 375 such-like statements were fixed, what makes a bit more than $50 \%$ from the total number of all the statements. The second position in frequency is taken by the statements, the subject of which was presented by the group of representatives of profession (207 references or 27.8\%). Correspondingly, the part of references to the profession in general or all its holders made up $22.1 \%$ (166 references).

The specificity of mentioned subjects for " 1 man" and "the group" units of analysis were also fixed. The specificity should be understood to mean the presence of person's name (or names, if we talk about the group) in the text. It was found that 316 references were linked to specific people. Thus, $42 \%$ of all the references are of personified character. Perhaps in such a case the professional activities of a man are statedly perceived by person through the prism of profession holder's personality.

Now we should considerate the grouping of references' totality in gender feature. The gender was fixed only in the case, if the subject of statement was one man and if his belonging to definite gender had not raised doubts. Thus, among the total number 315 such-like references (42.1\%) was fixed. Among them there were 263 references to males $(35.1 \%)$ and 52 - to females $(7 \%)$.

In such a manner, in the process of analysis we have proven the most important research hypothesis that states the most part of professions remains beyond the attention of mass media. The 82 professions fixed in the course of analysis make only $1 \%$ from all the professions, which exist today on the territory of the Russian Federation. We have also proven the hypothesis about existence of the hierarchy of professions in the materials of a newspaper.

The main conclusions made on the basis of primary analysis are the following. The level of interest in the matters of professional activities is quite high in the analyzed print media. However, journalists take interest in and, consequently, touch upon rather narrow range of professions.

We have also noticed that in the majority of cases ( $85.6 \%$ of references) the information about profession comes from a journalist and not from a direct specialist of the present area.

The images of professions in the half of cases bear personified character, i.e.- - the reference subject is presented with one specific man. Thus, the profession is often perceived by reader through the prism of personal skills of its holder.

We have suggested to measure the adequateness of reflection of professional activity problematics on the basis of comparison of various allocations (in the examined case, the allocation of employed population by professional 
groups formed in all-Russian classifier of professions; the allocation of professions' references in the materials of mass media; the allocation that demonstrates the existing demand for specialists; the allocation reflecting the level of wage and also the allocation of professions by status value) in the frameworks of regression model construction.

We have calculated the indexes of adequateness, which will show how accurately the mass media informs the society about what professional structure is necessary for society on the present stage for stable functioning and reproduction and also about the real social demand for specialists.

The main purpose for constructing model of multiple regressions implies the definition of what factors to the fullest extent influence the formation of the image of professional structure of society in mass media. To meet this purpose we should research the character of interrelations between the image of professional structure in mass media and the set of independent variables including professional structure of Russian society, demand for specialists, average level of wages by professional groups and also the status of professions.

So, as the independent variable $x_{l}$ we have taken the professional structure of Russian society-the structure of employed population allocated by different categories of professions as of the end of 2013 according to the data of Rosstat. The system of categories (total-28 categories) was brought into conformity with all-Russian classifier of occupations. The independent variable $x_{2}$ reflects the demand for specialists for substitution of vacant positions by different professional groups in 2013 according to the data of Rosstat. The variable $x_{3}$ is presented with average wage for each of the professional groups. The variable $x_{4}$ reflecting the status of professions belonging to these or those professional groups was made on the basis of results of public-opinion polls for 2013 according to the data of all-Russian Center of public opinion research (wciom. ru).

As the dependent variable $y$ we have taken the image of professional structure of Russian society in mass media - the quantity of references to professions in newspaper publications allocated by the categories of all-Russian classifier of occupation.

The goals of constructing regression model: confirmation or rejection of hypothesis about existence of relation between the independent factors and the image of professional structure in mass media; definition of parameters of such a relation.

The linear regression $y=b_{0}+b_{1} x_{1}+b_{2} x_{2}+b_{3} x_{3}+b_{4} x_{4}$.

Let us formulate the null and alternative hypotheses:

- The null hypothesis $H_{o}$ : there is no linear dependence between the four predictors and the structure of references to professions in mass media;

- The alternative hypotheses $H_{a}$ : there is linear dependence between the predictors and structure of references to professions in mass media.

Table 3. The results of analysis of regression

\begin{tabular}{|c|c|c|c|c|c|}
\hline \multicolumn{2}{|c|}{ SUMMARY OUTPUT } & & & & \\
\hline \multicolumn{2}{|l|}{ Regression Statistics } & & & & \\
\hline Multiple R & 0.899727 & & & & \\
\hline R Square & 0.809509 & & & & \\
\hline Adjusted R Square & 0.755083 & & & & \\
\hline Standard Error & 4.841451 & & & & \\
\hline Observations & 19 & & & & \\
\hline \multicolumn{6}{|l|}{ ANOVA } \\
\hline & $d f$ & $S S$ & $M S$ & $F$ & Significance $F$ \\
\hline Regression & 4 & 1394.527 & 348.6317 & 14.87359 & $6.07 \mathrm{E}-05$ \\
\hline Residual & 14 & 328.155 & 23.43964 & & \\
\hline Total & 18 & 1722.682 & & & \\
\hline
\end{tabular}




\begin{tabular}{lllll}
\hline & Coefficients & Standard Error & $t$ Stat & P-value \\
\hline Intercept & -2.99817 & 2.769886 & -1.08241 & 0.29736 \\
x1 & 0.000842 & 0.000805 & 1.044898 & 0.313777 \\
x2 & -0.04587 & 0.047026 & -0.97552 & 0.345859 \\
x3 & 0.000422 & 0.000409 & 1.030162 & 0.320403 \\
x4 & 8.939458 & 3.369837 & 2.652787 & 0.018926 \\
\hline
\end{tabular}

Thus, the equation of regression is the following:

$$
\hat{y}_{x}=0.00084 x_{1}-0.0469 x_{2}+0.00042 x_{3}+8.94 x_{4}-2.99
$$

For the purpose of further analysis and interpretation of obtained parameters it is necessary to perform the test of significance of equation of regression in general or, in other words, perform the test of adequateness of model. This task can be solved by the way of calculation of F-criterion of Fisher and its comparison with table (critical) criteria.

The table value $F$ for $v_{1}=4, v_{2}=14$ and $\alpha=0.05$ makes $F_{\text {table }}=3.11$.

$F_{\text {calc. }}=14.87$

$F_{\text {calc. }}>F_{\text {table }}$

Consequently, the equation of regression is being statistically significant. The obtained value points out the necessity of accepting the hypothesis about non-random nature of defined dependence and statistical significance of parameters of equation and the indicator of correlation ratio.

The coefficient of determination $R^{2}$ shows what part in general dispersion of resultative feature is taken by the dispersion that expresses the influence of independent factors on the variation of dependent feature $y$.

$R^{2}=0.809$

The obtained coefficient of determination shows that the variation of references to different professional groups depends on the factors introduced to regression for $80.9 \%$. The residual percent of variation is explained with the majority of other factors that were not introduced to the model.

Now, let us calculate the coefficient of multiple correlation. The coefficient of correlation expresses the intensity of interrelation between dependent and independent variables in non-dimensional scale from -1 to 1 . The positive correlation means the strong positive interrelation, i.e.- - the increase of one variable causes the decease of another one. The correlation being close to zero means either there is no interrelation between two variables at all, or that there is non-linear interrelation between them.

Most commonly to calculate the correlation one uses the Pearson correlation coefficient, which is denoted with $\mathrm{r}$ symbol. As a rule, the relation is considered as strong, if $|r| \geq 0.7$; medium—at $0.5 \leq|r|<0.7$; weak-at $|r|$ $<0.5$.

In the studied case the coefficient of multiple correlation makes $r=0.899$. This allows us to consider that the image of professional structure in mass media correlates with the present set of independent variables to the great degree.

Further we will examine the matrix of coefficients of pair correlation and evaluate the statistical significance of factors to define how reasonably it is to introduce this or that factor to the model.

The values of coefficients of pair correlation define the intensity of the variables that were related by couples and used in the present equation of multiple regressions (Table 4). 
Table 4. The values of coefficients of pair correlation

\begin{tabular}{|c|c|c|c|c|c|}
\hline Indicators & $\begin{array}{lr}\text { The image } & \text { of } \\
\text { professional structure } \\
\text { in mass } \\
\text { References } \\
\text { professions } \\
y\end{array}$ & $\begin{array}{l}\text { List-based } \\
\text { number of } \\
\text { workers-total, } \\
\text { thous. men } \\
x_{1}\end{array}$ & $\begin{array}{l}\text { Demand for workers } \\
\text { for substitution of } \\
\text { vacant work places, } \\
\text { thous. men } x_{2}\end{array}$ & $\begin{array}{l}\text { Average } \\
\text { wage by } 28 \\
\text { groups } x_{3}\end{array}$ & $\begin{array}{l}\text { Status value } \\
x_{4}\end{array}$ \\
\hline $\begin{array}{lr}\text { The image of } \\
\text { professional structure } \\
\text { in mass media. } \\
\text { References } \\
\text { professions }\end{array}$ & & & & & \\
\hline$y$ & 1 & & & & \\
\hline $\begin{array}{l}\text { List-based number of } \\
\text { workers-total, } \\
\text { thous. men } x_{1}\end{array}$ & 0.080091 & 1 & & & \\
\hline $\begin{array}{l}\text { Demand for workers } \\
\text { for substitution of } \\
\text { vacant work places, } \\
\text { thous. men } x_{2}\end{array}$ & -0.1074 & 0.861103 & 1 & & \\
\hline $\begin{array}{l}\text { Average wage by } 28 \\
\text { groups } x_{3}\end{array}$ & 0.836142 & 0.111027 & -0.04485 & 1 & \\
\hline Status value $x_{4}$ & 0.878761 & 0.0024 & -0.12616 & 0.867087 & 1 \\
\hline
\end{tabular}

As we can see from Table 4, between the image of professional structure in mass media and the demand for specialists there is practically no relation, while the image in mass media and the professional structure of society correlate weakly. At the same time, between the average wage and the status value of professions there is strong correlation.

Now let us find out what predictors possess the biggest statistical significance. For this purpose we will conduct the t-tests of coefficients.

The sufficient statistical significance is possessed only by the coefficients at predictors - the wage level and the status value of profession. The lowest statistical significance is bore by the coefficient at "The public demand for specialist" variable $\left(x_{2}\right)$. In such a way, we can exclude the present variable from the model due to its low informativity.

In accordance with the results of analysis of pair correlations and t-tests of coefficients of regression, we can conclude that the factors reflecting the professional structure of society and the public demand for specialists have minimal impact on the formation of the image of professional structure in mass media, while the average level of wage and the status value of profession generally define in what way the professional structure of society is represented in mass media.

Having put off the variable "The public demand for specialists" $\left(x_{2}\right)$ and constructed the three-factor regression model, with help of t-test we found out that the variable "The professional structure of society" can also be excluded as statistically insignificant (Table 5). 
Table 5. The results of analysis of regression

\begin{tabular}{|c|c|c|c|c|c|}
\hline \multicolumn{2}{|c|}{ SUMMARY OUTPUT } & & & & \\
\hline \multicolumn{2}{|c|}{ Regression Statistics } & & & & \\
\hline Multiple R & 0.892503 & & & & \\
\hline R Square & 0.796561 & & & & \\
\hline Adjusted & $\mathrm{R}$ & & & & \\
\hline Square & 0.755873 & & & & \\
\hline Standard Error & 4.833639 & & & & \\
\hline Observations & 19 & & & & \\
\hline \multicolumn{6}{|l|}{ ANOVA } \\
\hline & $d f$ & $S S$ & $M S$ & $F$ & Significance $F$ \\
\hline Regression & 3 & 1372.221 & 457.407 & 19.57737 & $1.91 \mathrm{E}-05$ \\
\hline Residual & 15 & 350.461 & 23.36407 & & \\
\hline \multirow[t]{2}{*}{ Total } & 18 & 1722.682 & & & \\
\hline & Coefficients & $\begin{array}{l}\text { Standard } \\
\text { Error }\end{array}$ & $t$ Stat & P-value & Lower 95\% \\
\hline Intercept & -3.20586 & 2.757236 & -1.16271 & 0.263113 & -9.08277 \\
\hline $\mathrm{x} 1$ & 0.00016 & 0.000399 & 0.399654 & 0.695045 & -0.00069 \\
\hline$x 3$ & 0.000471 & 0.000406 & 1.16028 & 0.264069 & -0.00039 \\
\hline $\mathrm{x} 4$ & 9.007738 & 3.363674 & 2.677946 & 0.017202 & 1.838237 \\
\hline
\end{tabular}

Further we should construct the regression model studying the impact of average wage and the status value of profession on the structure of references to professions in mass media (Table 6).

Table 6. The results of analysis of regression

\begin{tabular}{|c|c|c|c|c|c|}
\hline \multicolumn{2}{|c|}{ SUMMARY OUTPUT } & & & & \\
\hline \multicolumn{2}{|c|}{ Regression Statistics } & & & & \\
\hline Multiple R & 0.891288 & & & & \\
\hline R Square & 0.794395 & & & & \\
\hline $\begin{array}{l}\text { Adjusted } \\
\text { Square }\end{array}$ & 0.768694 & & & & \\
\hline Standard Error & 4.705003 & & & & \\
\hline Observations & 19 & & & & \\
\hline \multicolumn{6}{|l|}{ ANOVA } \\
\hline & $d f$ & $S S$ & $M S$ & $F$ & Significance $F$ \\
\hline Regression & 2 & 1368.489 & 684.2446 & 30.90948 & $3.19 \mathrm{E}-06$ \\
\hline Residual & 16 & 354.1928 & 22.13705 & & \\
\hline \multirow[t]{2}{*}{ Total } & 18 & 1722.682 & & & \\
\hline & Coefficients & $\begin{array}{l}\text { Standard } \\
\text { Error }\end{array}$ & t Stat & $P$-value & \\
\hline Intercept & -2.84437 & 2.535337 & -1.12189 & 0.278463 & \\
\hline $\mathrm{x}_{3}$ & 0.000506 & 0.000385 & 1.313596 & 0.207507 & \\
\hline $\mathrm{x}_{4}$ & 8.752848 & 3.214764 & 2.722703 & 0.015055 & \\
\hline
\end{tabular}


Thus, the equation of regression is the following:

$$
\hat{y}_{x}=0.000506 x_{3}+8.75 x_{4}-2.8
$$

The test of significance of equation of regression shows that $\mathrm{F}_{\text {calc. }}>\mathrm{F}_{\text {table. }}$.

The table value $\mathrm{F}$ for $v_{1}=4, v_{2}=14$ and $\alpha=0.05$ makes up $\mathrm{F}_{\text {table }}=3.11$.

$F_{\text {calc. }}=30.91$

Consequently, the equation of regression is being statistically significant. The obtained value points out the necessity of accepting the hypothesis about non-random nature of defined dependence and statistical significance of parameters of equation and the indicator of correlation ratio.

The coefficient of determination $R^{2}$ shows what part in general dispersion of resultative feature is taken by the dispersion that expresses the influence of independent factors on the variation of dependent feature $y$.

$R^{2}=0.794$

The obtained coefficient of determination shows that the variation of references to different professional groups depends on the factors introduced to regression for $79.4 \%$. The residual percent of variation is explained with the majority of other factors that were not introduced to the model.

The coefficient of multiple correlation makes $r=0.899$. This allows us to consider that the image of professional structure in mass media correlates with the present set of independent variables to the great degree.

Further we will examine the matrix of coefficients in pair correlation (Table 7).

Table 7. The values of coefficients of pair correlation

\begin{tabular}{|c|c|c|c|c|}
\hline & & $\begin{array}{l}\text { The image of } \\
\text { professional structure in } \\
\text { mass media. References } \\
\text { to professions, } \%\end{array}$ & $\begin{array}{l}\text { Average wage } \\
\text { by } 28 \text { groups }\end{array}$ & Status value \\
\hline & & $y$ & $x 3$ & $x 4$ \\
\hline $\begin{array}{l}\text { The image of } \\
\text { professional structure in } \\
\text { mass media. References } \\
\text { to professions, } \%\end{array}$ & $y$ & 1 & & \\
\hline $\begin{array}{l}\text { Average wage by } 28 \\
\text { groups }\end{array}$ & $x 3$ & 0.836142053 & 1 & \\
\hline Status value & $x 4$ & 0.87876098 & 0.867087199 & 1 \\
\hline
\end{tabular}

However, the t-tests of coefficients show the statistical insignificance of coefficient at variable "Average wage". This means that, most probably, there is non-linear dependence between the variables.

Now let us examine the possibility of quadratic dependence. For this purpose we should add $\mathrm{x}_{3}{ }^{2}$ and $\mathrm{x}_{4}{ }^{2}$ variables to the model (Table 8). 
Table 8 . The test of model for quadratic dependence

\begin{tabular}{lc}
\hline \multicolumn{2}{l}{ SUMMARY OUTPUT } \\
\hline \multicolumn{2}{l}{ Regression Statistics } \\
\hline Multiple R & 0.955835 \\
R Square & 0.91362 \\
Adjusted $\quad \mathrm{R}$ & \\
Square & 0.88894 \\
Standard Error & 3.260206 \\
Observations & 19
\end{tabular}

\begin{tabular}{|c|c|c|c|c|c|}
\hline \multicolumn{6}{|l|}{ ANOVA } \\
\hline & $d f$ & $S S$ & $M S$ & $F$ & Significance F \\
\hline Regression & 4 & 1573.877 & 393.4692 & 37.01865 & $2.65 \mathrm{E}-07$ \\
\hline Residual & 14 & 148.8052 & 10.62894 & & \\
\hline \multirow[t]{2}{*}{ Total } & 18 & 1722.682 & & & \\
\hline & Coefficients & $\begin{array}{l}\text { Standard } \\
\text { Error }\end{array}$ & $t$ Stat & $P$-value & \\
\hline Intercept & -11.3697 & 3.946027 & -2.8813 & 0.01208 & \\
\hline $\mathrm{x}_{3}$ & 0.002509 & 0.00075 & 3.344708 & 0.004814 & \\
\hline $\mathrm{x}_{4}$ & -6.44525 & 4.366435 & -2.0476 & 0.2056 & \\
\hline $\mathrm{x}_{5}$ & $-8.8 \mathrm{E}-08$ & $2.31 \mathrm{E}-08$ & -3.79215 & 0.001981 & \\
\hline $\mathrm{x}_{6}$ & 10.89701 & 2.990917 & 3.643366 & 0.00266 & \\
\hline
\end{tabular}

Regression equation is the following:

$$
\hat{y}_{x}=-8.8\left(10^{-8}\right) x_{3}^{2}+0.025 x_{3}+10.9 x_{4}^{2-} 6.45 x_{4}-11.3
$$

The correlation index makes up $\rho=0.956$. This allows us to consider that the image of professional structure of society in mass media correlates with average wage and status value of profession to the great degree.

The coefficient of determination $R^{2}=0.914$.

The obtained coefficient of determination shows that the variation of references to different professional groups depends on the average wage and the status value of professional groups for $91.4 \%$.

At the same time the t-tests of coefficients show the statistical insignificance of the coefficient at variable "Status value". This means the present model is not being statistically significant.

Let us introduce another one variable into the model. The variable will be presented with the product of two variables - the Average rage multiplied by the Status value (Table 9). 
Table 9. The results of analysis of the model in case of introducing a new variable

\begin{tabular}{|c|c|c|c|c|c|}
\hline \multicolumn{2}{|c|}{ SUMMARY OUTPUT } & & & & \\
\hline \multicolumn{2}{|l|}{ Regression Statistics } & & & & \\
\hline Multiple R & 0.977985 & & & & \\
\hline R Square & 0.956455 & & & & \\
\hline Adjusted R Square & 0.944013 & & & & \\
\hline Standard Error & 2.31478 & & & & \\
\hline Observations & 19 & & & & \\
\hline \multicolumn{6}{|l|}{ ANOVA } \\
\hline & $d f$ & $S S$ & $M S$ & $F$ & Significance $F$ \\
\hline Regression & 4 & 1647.667 & 411.9168 & 76.87584905 & $2.28463 \mathrm{E}-09$ \\
\hline Residual & 14 & 75.01491 & 5.358208 & & \\
\hline \multirow[t]{2}{*}{ Total } & 18 & 1722.682 & & & \\
\hline & Coefficients & $\begin{array}{l}\text { Standard } \\
\text { Error }\end{array}$ & $t$ Stat & P-value & \\
\hline Intercept & -11.70595 & 2.801668 & -4.17821 & 0.000929102 & \\
\hline $\mathrm{x}_{3}$ Average wage & 0.003421 & 0.000563 & 6.081489 & $2.83057 E-05$ & \\
\hline $\mathrm{x}_{4}$ Status value & -15.03586 & 3.853968 & -3.9014 & 0.001597356 & \\
\hline$x_{3}{ }^{2}$ & $-2.18 \mathrm{E}-07$ & $3.02 \mathrm{E}-08$ & -7.21782 & 4.4401E-06 & \\
\hline $\mathrm{x}_{3} * \mathrm{x}_{4}$ & 0.002436 & 0.000385 & 6.332692 & 1.85112E-05 & \\
\hline
\end{tabular}

The equation of regression is the following:

$$
\hat{y}=0.034 x_{3}-15.036 x_{4}-0.00000022 x_{3}^{2}+0.0024 x_{3} x_{4}-11.71
$$

The correlation index makes up $\rho=0.98$. This allows us to consider that the image of professional structure of society in mass media correlates with the average wage and the status value of professions to the extremely great degree.

The coefficient of determination $R^{2}=0.96$.

The obtained coefficient of determination shows that the variation of references to different professional groups depends on the average wage and the status value of professional groups for $96 \%$.

Further we will examine the matrix of coefficients of pair correlation.

Let us calculate the Fisher's F-criterion and compare it with table (critical) values.

The table value $\mathrm{F}$ for $v_{1}=1, v_{2}=14$ and $\alpha=0.05$ makes up $\mathrm{F}_{\text {table }}=3.11$.

$\mathrm{F}_{\text {calc. }}=76.9$

$\mathrm{F}_{\text {calc. }}>\mathrm{F}_{\text {table }}$

The obtained values witness statistical significance of the model and non-random nature of specified interrelations.

Now let us conduct t-tests of coefficients of regression equation with the level of significance being equal to 0.05 and 14 degree of variance $t=2.15$ (Table 10 ). 
Table 10. The results of t-tests of coefficients of regression equation

\begin{tabular}{|c|c|c|c|}
\hline Independent variables & & Indexes & t actual \\
\hline & & $\mathbf{b}_{\mathbf{0}}$ & -4.17821 \\
\hline Average wage by 28 groups & $\mathrm{x}_{3}$ & $\mathbf{b}_{1}$ & 6.081489 \\
\hline Status value $\quad \mathrm{x} 4$ & & $b_{2}$ & -3.9014 \\
\hline $\mathrm{x}_{3}^{2}$ & & $\mathbf{b}_{3}$ & -7.21782 \\
\hline $\mathrm{x}_{3}{ }^{*} \mathrm{x}_{4}$ & & $\mathbf{b}_{4}$ & 6.332692 \\
\hline
\end{tabular}

All the $t_{\text {actual }}$ in modulus exceed 2.15 , consequently we can make a conclusion about statistical significance of all the coefficients of equation of regression, what provides grounds for their further interpretation.

The present regression model proves the presence of strong dependence between the image of professional structure of society in mass media, the level of wage and the status value of professions. The obtained determination coefficient shows that the variation of references to different professional groups depends on the average wage and the status value of professional groups for $96 \%$.

Now let us examine how the value-based effects appear in consumer field of audience after consumption of information from mass media. For this purpose we should evaluate for how much the impact of mass media determines the opinions of population in matters of being in demand and status value of these or those professions.

For this purpose we will calculate the indexes of adequateness to mass consciousness.

$$
i_{x y}=1-\frac{d(x, y)}{d_{\max \square}},
$$

where $d_{\max }$ is maximum possible difference.

$$
d(x, y)=\sum\left|x_{t}-y_{t}\right|
$$

where $x$ and $y$ are the allocations of compared features.

Next, we should calculate the index of adequateness to mass consciousness on the basis of comparison of informational image and status value of professions in the consciousness of audience (Table 11).

Table 11. The allocations characterizing the image of professional structure in mass media and the status value of

\begin{tabular}{|c|c|c|c|}
\hline $\begin{array}{l}\text { Year } \\
2013\end{array}$ & Representatives of professions & $\begin{array}{l}\text { Image of professional } \\
\text { structure in mass media }\end{array}$ & $\begin{array}{l}\text { Opinion about status } \\
\text { value of professions } \\
\text { (the polling } \\
\text { WCIOM) }\end{array}$ \\
\hline & & References, $\%$ & $\%$ \\
\hline 1 & $\begin{array}{l}\text { Heads of organizations and enterprises and their } \\
\text { structural sub-divisions (services) }\end{array}$ & 21.1 & 15.0 \\
\hline 2 & Specialists of higher level of qualification & 51.6 & 73.3 \\
\hline 3 & Specialists of medium level of qualification & 20.5 & 0.0 \\
\hline 4 & $\begin{array}{l}\text { Workers engaged into preparation of information, } \\
\text { drawing up of documentation, accounting and }\end{array}$ & 0.8 & 0.0 \\
\hline
\end{tabular}
professions in the consciousness of audience 


\section{servicing}

Workers of services sector, housing and utilities

5 infrastructure, trade and related types of activity

Qualified workers of agricultural, forest, hunting

Qualified workers of industrial enterprises, artistic business, construction, transport, communication,

Operators, machine politicians, machinists of units

9 Unskilled labour $\quad 0.9 \quad 0.0$

\begin{tabular}{lll}
\hline Total & 100 & 100 \\
\hline
\end{tabular}

$$
i_{x y}=1-\frac{3,9}{200}=0.98
$$

This means that the audience's opinion about status value of professions is being almost fully adequate to the content of materials of mass media. Consequently, we can suppose that the level of effectiveness of influence of mass media on the audience is extremely high.

Now we will calculate the index of adequateness to mass consciousness on the basis of comparison of informational image and opinion about the state of being in demand regarding professions (Table 12).

Table 12. Allocations characterizing the image of professional structure in mass media and the state of being in demand regarding professions in the consciousness of audience

\begin{tabular}{|c|c|c|c|}
\hline 2013 & Representatives of professions & $\begin{array}{l}\text { Image of professional } \\
\text { structure in mass media }\end{array}$ & $\begin{array}{l}\text { Opinion about the state } \\
\text { of being in demand } \\
\text { regarding professions } \\
\text { (the polling of } \\
\text { WCIOM) }\end{array}$ \\
\hline & & References, $\%$ & $\%$ \\
\hline 1 & $\begin{array}{l}\text { Heads of organizations and enterprises and their } \\
\text { structural sub-divisions (services) }\end{array}$ & 21.1 & 14.6 \\
\hline 2 & Specialists of higher level of qualification & 51.6 & 69.3 \\
\hline 3 & Specialists of medium level of qualification & 20.5 & 5.1 \\
\hline 4 & $\begin{array}{l}\text { Workers engaged into preparation of information, } \\
\text { drawing up of documentation, accounting and } \\
\text { servicing }\end{array}$ & 0.8 & 0 \\
\hline 5 & $\begin{array}{l}\text { Workers of services sector, housing and utilities } \\
\text { infrastructure, trade and related types of activity }\end{array}$ & 0.2 & 5.1 \\
\hline 6 & $\begin{array}{l}\text { Qualified workers of agricultural, forest, hunting } \\
\text { sectors, pisciculture and fishery }\end{array}$ & 0.5 & 0.8 \\
\hline 7 & $\begin{array}{l}\text { Qualified workers of industrial enterprises, artistic } \\
\text { business, construction, transport, communication, } \\
\text { geology and exploration }\end{array}$ & 1.8 & 5.1 \\
\hline
\end{tabular}




\begin{tabular}{llll}
\hline \multirow{2}{*}{8} & Operators, machine politicians, machinists of units & & \\
9 & and mechanisms & 2.6 & 0 \\
& Unskilled labour & 0.9 & 0 \\
\hline & Total & 100 & 100 \\
\hline
\end{tabular}

$$
i_{x y}=1-\frac{52,4}{200}=0.74
$$

This means that the audience opinion about the state of being in demand regarding professions is rather adequate to the content of materials of mass media.

\section{Conclusions}

In accordance with the results of analysis of regression models, we can make the conclusion that the factors reflecting professional structure of society and public demand for specialists have minimal impact on the formation of image of professional structure in mass media, while the average level of wage and status value of profession generally define in what way the professional structure of society is represented in mass media.

On the basis of analyzed regression models we can make the following conclusions on how effectively the printed mass media manage with their social functions and what impact they have on audience in matters of formation of professional and qualification preferences.

As a whole the analyzed mass media show extremely low effectiveness in regard to informing population about existing professional structure of Russian society, what, to our mind, destructively influences the formation of professional structure in future and just increases the existing imbalance of the structure and serious deficit of skilled workers in some areas of activities.

What is for the stage of influence of mass media on audience, the conducted research has shown that mass media have an impact on audience's opinion about status value and professions' state of being in demand with extremely high degree of effectiveness. Thus, the affected audience relates the status value and professions' state of being in demand with high consumer level that provides the present kind of occupations, although in practice we can trace such an interrelation far not always. This proves that mass media are being the most powerful instrument for formation of consumer field of audience and, particularly, its professional and qualification preferences, which are being the basis for formation of professional structure of society.

Thus, we can certainly say that mass media can serve as effective regulator in the process of formation of professional and qualification structure of society that would be adequate to public demands for specialists of this or that profession. To improve the situation it is necessary to correct the image of professional structure that is broadcasted to audience in accordance with public demands.

\section{Acknowledgment}

The corporate authors extend appreciation to Skitovich Vladimir Viktorovich, the Candidate of physico-mathematical sciences and associated professor of department of social analysis and mathematical methods in sociology of St. Petersburg State University for consultations on selecting the research methods.

\section{References}

Afanasev, V. G. (1975). Social information and society management. Moscow: Politizdat.

Bagirov, E. G. (1978). Television theory essays. Moscow: Iskusstvo.

Baudrillard, J. (2000). In the Shadow of the Silent Majorities or the End of the Social. Ekaterinburg: Ural University Press.

Baudrillard, J. (2006). Consumer society: Its myths and structures. Moscow: Kulturnaya Revolutsiya.

Belyaev, I. (2005). Performance of documents: Television revelations. Moscow: Gelios.

Berelson, B. (1966). The Effects of Print on Public Opinion. Chicago: Watson \& Spike.

Berger, A. A. (2014). Media and Communication Research Methods: An Introduction to Qualitative and Quantitative Approaches. London: Sage Publications Inc.

Boretsky, R. A. (1993). Watch out, television! Moscow: Ikar. 
Bryant, J., \& Oliver, M. B. (2009). Media Effects: Advances in Theory and Research. New York and London: Routledge.

Castells, M. (2000). End of Millennium, The Information Age: Economy, Society and Culture. Oxford, UK: Blackwell.

Cherednichenko, G. A. (2004). Youth of Russia: Social orientation and ways of living. St. Petersburg: Nauka.

Cherednichenko, G. A., \& Shubkin, V. N. (1985). Youth Enter Upon Life. Moscow: Nauka.

DeFleur, M. L., \& Ball-Rokeach, S. (1996). Theories of mass communication. New York : Longman.

Egorov, V. V. (1998). Television: Theory and practice. Moscow: International independent ecologic \& politologic university.

Ershov, P. M. (1990). Human Needs. Moscow: Mysl.

Filippov, F. R. (1980). Sociology of Education. Moscow: Mysl.

Filippov, F. R. (1989). From Generation to Generation. Moscow: Mysl.

Giddens, A. (2004). How Globalization is Reshaping Our Lives. Moscow: Ves mir.

Habermas, J. (2000). Moral Consciousness and Communication Action. St. Petersburg: Nauka.

Hovland, C. I., Janis, I. L., \& Kelly, H. H. (1964). Communication and persuasion. New Haven, London: Yale University press.

Lasswell, H. D. (1927). Propaganda Technique in the World War. London: K. Paul, Trench, Trubner \& co., ltd.; New York : A. A. Knopf.

Lazarsfeld, P. (1940). Radio and the Printed Page: An Introduction to the Study of Radio and Its Role in the Communication of Ideas. New York: Duell, Sloan, and Pearce.

Lippmann, W. (2004). Public Opinion. Moscow: Obschestvennoe mnenie.

Lule, J. (2014). Understanding Media and Culture: An Introduction to Mass Communication. New York: Flat World Education.

Malinina, T. B. (2014). Culture as an Information System. Global Scientific Potential, 8(41), 43-47.

McLuhan, М. (2003). Понимание Медиа : Внешние расширения человека. Moscow: Канон-пресс-Ц.

McQuail, D. (1994). Mass Communication Theory: An Introduction. London: Sage Publications.

Mihalkovich, V. I. (1996). Television Theory Essay. Moscow: Art Studies Institute.

Noelle-Neumann, E. (1993). The spiral of silence: Public opinion, our social skin. Chicago: University of Chicago Press.

Russian Classifier of Occupations. (2005). Moscow: StandartInform.

Russian National Classifier of Occupations of Employees, Positions of Civil Servants and Wage Category. (2006). Moscow: StandartInform.

Schiller, G. (1980). Consciousness manipulators. Moscow: Politizdat.

Schramm, W. (1960). Mass Communication. University of Illinois Press.

Shannon, K. (1963). Theory of information and cybernetics works. Moscow: Inostrannaya literatura.

Sorokin, P. (1970). Social and Cultural Dynamics: A Study of Change in Major Systems of Art, Truth, Ethics, Law and Social Relationships. Boston: Extending Horizons Books, Porter Sargent Publishers.

Toffler, E. (2010). Third Wave. Moscow: AST.

Weber, M. (1991). Works of Weber M. on sociology, religion, and culture. Moscow: INION.

Wiener, N. (1958). Cybernetics and society. Moscow: Inostrannaya literatura.

Wimmer, R. D., \& Dominick, J. R. (2013). Mass Media Research (Wadsworth Series in Mass Communication and Journalism). Boston: Wadsworth Publishing.

Zaller, J. (2004). Origin and nature of public opinion. Moscow: Institute of Obschestvennoe Mnenie fund.

Zdravomyslov, A. G. (1986). Needs. Interests. Values. Moscow: Politizdat. 


\section{Copyrights}

Copyright for this article is retained by the author(s), with first publication rights granted to the journal.

This is an open-access article distributed under the terms and conditions of the Creative Commons Attribution license (http://creativecommons.org/licenses/by/3.0/). 